\title{
EFFECT OF ACTIVATION OF THE GLT-1 TRANSPORTER BY A BETA-LACTAM ANTIBIOTIC ON SEROTONIN-INDUCED SCRATCHING BEHAVIOR IN MICE
}

\begin{abstract}
Received February 17, 2014
Glutamate is believed to be the predominant excitatory neurotransmitter in the networks responsible for itch-related behavior. Beta-lactam antibiotics were shown to exert neuroprotective effects by increasing expression of the glutamate transporter GLT-1. We observed whether repeated administration of the beta-lactam antibiotic ceftriaxone suppresses serotonin-induced itch-related behavior (similarly to its effect on pain transmission) in mice. Chronic, but not acute, ceftriaxone introductions reduced the number of serotonin-induced scratches; dihydrokainic acid, a selective GLT-1 transporter inhibitor, partly but significantly abolished this effect of ceftriaxone. Our findings suggest that GLT-1 activation by beta-lactam antibiotics looks promising for the treatment of chronic itch.
\end{abstract}

Keywords: ceftriaxone, glutamate transporter GLT-1, itch, serotonin.

\section{INTRODUCTION}

Glutamate is known to be a principal excitatory amino acid neurotransmitter in the CNS. A few glutamate transporters found in neuronal and glial membranes are primarily responsible for the regulation of extracellular glutamate homeostasis. Among these transporters, glutamate transporter-1 (GLT-1) removes at least $90 \%$ of extracellular glutamate and appears to play the pivotal role in terminating synaptic effects of this acid transmitter [1, 2]. Accordingly, drugs stimulating the GLT-1 expression are shown to offer neuroprotection [3]. Among these agents, ceftriaxone, a popular beta-lactam antibiotic, is being widely studied. It is suggested to contribute to possible effects in many clinical CNS disorders, including Parkinson's disease, stroke, epilepsy, visceral and neuropathic pain, and tolerance and dependence to drugs affecting the CNS [3-9]. In addition, it is under clinical trials for the treatment of amyotrophic lateral sclerosis.

Itch is an unpleasant (but protective) sensation that provokes the desire to scratch. Although pain and itch are distinct sensations, most noxious chemicals appear to be nonspecific with respect to these phenomena; moreover, spinal cord neuronal mechanisms are suggested to play a pivotal role not only in pain, but

${ }^{1}$ Department of Medical Pharmacology, Faculty of Medicine, Trakya University, Edirne (Turkey).

Correspondence should be addressed to (A. Ulugol)

(e-mail: aulugol@trakya.edu.tr; aulugol@yahoo.com). also in itch $[10,11]$. Recent researches showed that, similarly to pain sensation, glutamate acts as the major excitatory transmitter for synaptic transmission in the networks involved in the itch-related behavior [12]. As a result, the directions of antipruritic therapies are now expanding from the periphery (skin) to the CNS [13, 14]. Taking into consideration the similarities between itch and pain sensations, we investigated the effect of activation of the GLT-1 transporter by ceftriaxone on serotonin-induced scratching behavior in mice.

\section{METHODS}

Eight- to 12-week-old male Balb/c mice (Center of the Laboratory Animals, Trakya University) were used in the experiments. Animals were maintained under a controlled light cycle (12-12 h light-dark) and temperature $\left(21 \pm 2{ }^{\circ} \mathrm{C}\right)$ with water and food available ad libitum.

To provoke scratching behavior, $50 \mu \mathrm{g} / 50 \mu \mathrm{l}$ of serotonin was injected intradermally into the rostral part of the back of the experimental mice. Immediately after serotonin administration, the animals were put back into the same cages, and their behavior was videotaped for $30 \mathrm{~min}$; the experimenters remained outside the laboratory during this period. The number of scratching of the injected site by the hindpaws within the observation period was counted as an index of the scratching intensity. 
Naive mice were i.p. injected with either saline or ceftriaxone $(50,100$, or $200 \mathrm{mg} / \mathrm{kg})$ once daily for 7 days. On day 7, scratching behavior was induced by serotonin administration $30 \mathrm{~min}$ after ceftriaxone injection. In a separate animal group, a single injection of ceftriaxone $(200 \mathrm{mg} / \mathrm{kg}$, i.p.) was administered in order to evaluate its acute effect. To determine if GLT-1 activation mediates the ceftriaxone effect, the GLT-1 blocker, dihydrokainic acid (DHKA, $10 \mathrm{mg} / \mathrm{kg}$, i.p.), was co-administered with ceftriaxone for 7 days. Drug doses and treatment times were chosen according to previous reports $[5,6,15]$.

A commercial preparation of ceftriaxone (Rocephin, Roche, France) was used; DHKA was purchased from Tocris (Great Britain). Ceftriaxone and DHKA were dissolved in saline and administered i.p. in a volume of $0.1 \mathrm{ml} / 10 \mathrm{~g}$ body mass.

Analysis of variance (ANOVA) was used to carry out statistical comparisons among groups and followed by the Bonferroni $t$-test. Differences with $P$ values $<0.05$ were considered to be statistically significant. All data are expressed below as means \pm s.e.m.

\section{RESULTS}

In the control group of serotonin-injected mice, the mean number of scratches within the 30-min-long observation period was $46.6 \pm 7.6$ (Fig. 1, 1). In the

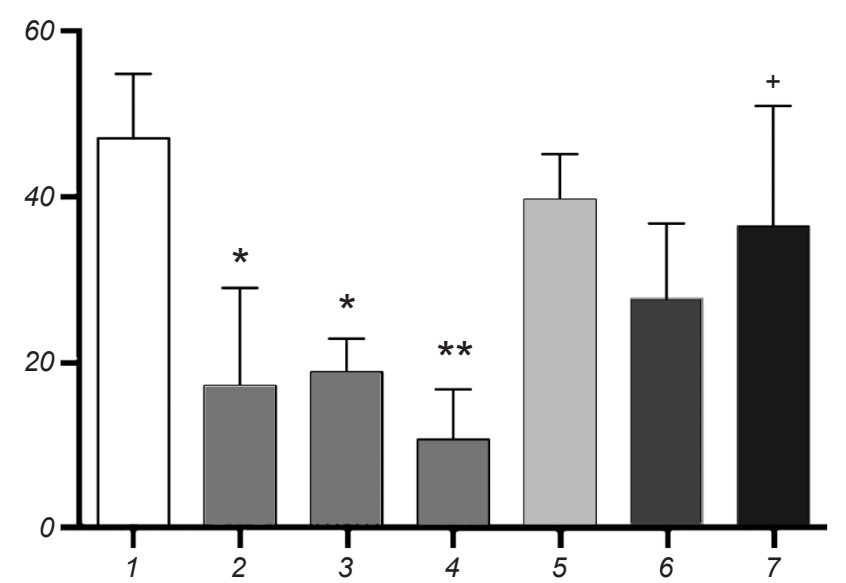

Diagram of the number of scratches performed by serotonin-ijected mice within the 30-min-long observation period. 1-7) Experimental groups, control (1), repeatedly injected with 50,100 , and $200 \mathrm{mg} / \mathrm{kg}$ ceftriaxone daily during 7 days (2-4, respectively), subjected to single $200 \mathrm{mg} / \mathrm{kg}$ ceftriaxon injections (5), to isolated $10 \mathrm{mg} / \mathrm{kg}$ DHKA injections (6), and to combined repeated injections of 200 $\mathrm{mg} / \mathrm{kg}$ ceftriaxone and $10 \mathrm{mg} / \mathrm{kg}$ DHKA (7).

Діаграма кількості чухальних рухів у мишей після ін'єкції серотоніну протягом 30-хвилинного періоду спостереження. groups treated with 50 and $100 \mathrm{mg} / \mathrm{kg}$ ceftriaxone, the number of scratches was by about $60 \%$ smaller than in the control $(P<0.05$; Fig. 1, 2 and 3$)$. In the group treated with the greatest dose of ceftriaxone $(200 \mathrm{mg} / \mathrm{kg})$, the intensity of suppression of scratching was higher, more than fourfold $(P<0.01$; Fig. 1, 4). Single injections of $200 \mathrm{mg} / \mathrm{kg}$ ceftriaxone provided some trend toward decrease in the number of scratches, but the difference from the control was insignificant (Fig. 1, 5). Isolated injections of DHKA decreased somewhat the number of scratches. The decrement was about $22 \%$, but the difference was insignificant (mostly because of considerable interindividual dispersion of the values; Fig. 1, 6). Introductions of DHKA combined with chronic injections of high doses of ceftriaxone $(200 \mathrm{mg} / \mathrm{kg})$ partly but rather significantly suppressed the protective effect of the above antibiotic. In the respective group, the number of scratches within the observation interval was about $60 \%$ of the control, i.e., the intensity of scratching was 2.5 times higher than in the group chronically treated with $200 \mathrm{mg} / \mathrm{kg}$ ceftriaxone but with no action of the above GLT-1 transporter inhibitor.

Therefore, ceftriaxone introductions reduced serotonin-induced scratching behavior with all the doses used, but only under condition of repeated (chronic) injections. Certain dose dependence was observed in this case; the highest doses $(200 \mathrm{mg} / \mathrm{kg}$ ) provided the greatest anti-itch effect; at the same time, the dependence at smaller doses was not obvious. The GLT-1 transporter inhibitor DHKA $(10 \mathrm{mg} / \mathrm{kg})$ elicited nearly no action in the case of isolated introduction but significantly abolished the inhibitory effect of ceftriaxone. No significant protective effect was observed in the case of acute ceftriaxone treatment.

\section{DISCUSSION}

Pain and itch are distinct but, at the same time, partly similar sensations, both switching on the alert systems to protect the organism of vertebrates from some noxious stimuli. In the periphery, noxious chemicals are not very specific with respect to pain or itch, and TRP channels are shown to be involved in mediating of both these phenomena $[10,16]$. Distinct subsets of itch-specific $\mathrm{C}$-fibers transmit signals from the skin to the superficial spinal dorsal horn regions $[17,18]$ and, subsequently, to the thalamus and some other suprasegmental structures $[11,18]$.

Spinal dorsal horn neuronal networks attract great 
attention of researchers, since these networks are suggested to play important roles in the formation of both pain and itch sensations $[10,11,13]$. Spinal opioids, gastrin-releasing peptide (GRP), glutamate, bradykinin, substance $P$, serotonin, and histamine receptors were shown (or expected) to be involved in itch, and targeting these spinal receptors by pharmacological agents seems promising for the development of new antipruritic drugs [14]. In addition, first inhibitory interneurons in itch-related networks have been identified in the dorsal spinal cord; loss or suppression of inhibition has been shown to cause pathological itch, similarly to abnormal pain [19]. Deletion of vesicular GLT-2 in the dorsal root ganglia augmented behavioral itch responses [20, 21]. Accordingly, similarly to the pain sensation, glutamate is proposed to be the major neurotransmitter for both GRP-sensitive and insensitive itch-related synaptic transmission in the spinal cord [12].

Chronic introductions of ceftriaxone were shown to exert anti-nociceptive effects in neuropathic rats; the respective events were considered resulting from specific up-regulation of GLT-1 expression in the spinal cord [8]. When the importance of the amount of released glutamate in the spinal dorsal horn for the itch phenomena is taken into consideration, it can be speculated that isolated action of DHKA should induce scratching behavior. However, we did not observe such effect after isolated administration of this agent. This may be related to an insufficient dose of DHKA. It should also be mentioned that the same dose of the above drug was used in pain studies without any effect on nociception [4-6].

Thus, we found that serotonin-induced scratching behavior is suppressed due to repeated treatment with ceftriaxone. In addition to increased expression and function of the GLT-1 in the brain, chronic ceftriaxone administration may also provide GLT-1 up-regulation in the spinal dorsal horn. Although the mechanism of anti-pruritic activity of the tested beta-lactam antibiotic awaits further exploration, our results indicate that GLT- 1 activation by this agent may be a promising option in pharmacotherapy of some chronic itch states.

The study was carried out in accordance with the statements of the Council Directive regarding the protection of animals used for experimental and other scientific purposes $(86 / 609 /$ EEC, 1986, Strasbourg). It was approved by the Animal Care Ethics Committee at the Trakya University, and conducted according to the guidelines of the Ethical Committee of the International Association for the study of pain.
The authors of this study, O. Gunduz, R. D. Topuz, Z. G. Todurga, K. Duvan, C. H. Karadag, and A. Ulugol, confirm that the research and publication of the results were not associated with any conflicts regarding commercial or financial relations, relations with organizations and/or individuals who may have been related to the study, and interrelations of coauthors of the article.

О. Гундуз ${ }^{l}$, Р. Д. Тонуз ${ }^{l}$, З. Г. Тодурга ${ }^{l}$, К. Дуван ${ }^{1}$, С. Х. Карадаг ${ }^{1}$ А. Улугал

\section{ВПЛИВ АКТИВАЦІЇ ГЛУТАМАТНОГО ТРАНСПОР- ТЕРА-1 $\beta$-ЛАКТАМНИМ АНТИБІОТИКОМ НА ВИКЛИКАНІ СЕРОТОНІНОМ ЧУХАЛЬНІ РУХИ У МИШЕЙ}

${ }^{1}$ Фракійський Університет, Едірне (Туреччина).

P е 3 ю м е

Як вважають, глутамат є основним збуджуючим нейротрансмітером у нейронних мережах, відповідальних за поведінкові моторні прояви при почутті свербіжу. $\beta$-лактамні антибіотики мають нейропротективні властивості, оскільки забезпечують посилену експресію глутаматного транспортера GLT-1. Ми з'ясовували, чи здатне повторне введення $\beta$-лактамного антибіотика цефтриаксону пригнічувати викликані ін'єкціями серотоніну поведінкові моторні прояви (чухальні рухи), пов'язані з індукцією почуття свербіжу (подібно до впливу цього агента на біль) у мишей. Хронічні (але не поодинокі) введення цефтриаксону викликали зменшення кількості рухів чухання. Селективний блокатор транспортера GLT-1 дигідрокаїнова кислота частково, але істотно перешкоджала цьому ефекту цефтриаксону. Наші спостереження дають підстави вважати, що активація GLT-1 $\beta$-лактамними антибіотиками є перспективним підходом у лікуванні хронічного свербіжу.

\section{REFERENCES}

1. N. C. Danbolt, “Glutamate uptake," Prog. Neurobiol., 65, No. 1, 1-105 (2001).

2. R. P. Seal and S. G. Amara, "Excitatory amino acid transporters: A family in flux," Annu. Rev. Pharmacol., 39, 431-456 (1999).

3. J. D. Rothstein, S. Patel, and M. R. Regan, et al., "Beta-lactam antibiotics offer neuroprotection by increasing glutamate transporter expression," Nature, 433, No. 7021, 73-77 (2005).

4. S. M. Rawls, M. Zielinski, H. Patel, et al., "Beta-lactam antibiotic reduces morphine analgesic tolerance in rats through GLT-1 transporter activation," Drug Alcohol Dependence, 107, Nos. 2/3, 261-263 (2010).

5. O. Gunduz, C. Oltulu, D. Buldum, et al., "Anti-allodynic and anti-hyperalgesic effects of ceftriaxone in streptozocin-induced diabetic rats," Neurosci. Lett., 491, No. 1, 23-25 (2011).

6. O. Gunduz, C. Oltulu, and A. Ulugol, "Role of GLT- 
1 transporter activation in prevention of cannabinoid tolerance by the beta-lactam antibiotic, ceftriaxone, in mice," Pharmacol. Biochem. Behav, 99, No. 1, 100-103 (2011).

7. A. Ulugol, "Reduction of dependence to cannabinoids by GLT-1 activating property of the beta-lactam antibiotic," Med. Hypoth., 80, No. 3, 247-248 (2013).

8. Y. Hu, W. Li, L. Lu, et al., "An anti-nociceptive role for ceftriaxone in chronic neuropathic pain in rats," Pain, 148, No. 2, 284-301 (2010).

9. V. L. Rao, K. K. Bowen, and R. J. Dempsey, "Transient focal cerebral ischemia down-regulates glutamate transporters GLT-1 and EAAC1 expression in rat brain," Neurochem. Res., 26, No. 5, 497-502 (2001).

10. S. E. Ross, "Pain and itch: insights into the neural circuits of aversive somatosensation in health and disease," Current Opin. Neurobiol., 2, No. 6, 880-887 (2011).

11. M. Schmelz, "Itch and pain," Neurosci. Biobehav. Rev., 34, No. 2, 171-176 (2010).

12. K. Koga, T. Chen, X.-Y. Li, et al., "Glutamate acts as a neurotransmitter for gastrin releasing peptide-sensitive and insensitive itch-related synaptic transmission in mammalian spinal cord," Mol. Pain, 7, 47 (2011).

13. T. Andoh, Y. Gotoh, and Y. Kuraishi, "Milnacipran 1nhibits 1tch-related responses in mice through the enhancement of noradrenergic transmission in the spinal cord," $J$. Pharmacol. Sci., 123, No. 2, 199-202 (2013).
14. F. Cevikbas, M, Steinhoff, and A. Ikoma, "Role of spinal neurotransmitter receptors in itch: New insights into therapies and drug development," CNS Neurosci. Ther., 17, No. 6, 742749 (2011).

15. I. Karaman, G. Kizilay-Ozfidan, C. H. Karadag, and A. Ulugol, "Lack of effect of ceftriaxone, a GLT-1 transporter activator, on spatial memory in mice," Pharmacol. Biochem. Behav., 108, 61-65 (2013).

16. B. L. Xiao and A. Patapoutian, "Scratching the surface: a role of pain-sensing TRPA1 in itch," Nat. Neurosci., 14, No. 5, 540-542 (2011).

17. D. Andrew and A. D. Craig, "Spinothalamic lamina I neurons selectively sensitive to histamine: a central neural pathway for itch," Nat. Neurosci., 4, No. 1, $72-77$ (2001).

18. A. Ikoma, M. Steinhoff, S. Stander, et al., "The neurobiology of itch," Nat. Rev. Neurosci., 7, No. 7, 535-547 (2006).

19. S. E. Ross, A. R. Mardinly, A. E. McCord, et al., "Loss of inhibitory interneurons in the dorsal spinal cord and elevated itch in Bhlhb5 mutant mice," Neuron, 65, No. 6, 886-898 (2010).

20. M. C. Lagerstrom, K. Rogoz, B. Abrahamsen, et al., "VGLUT2dependent sensory neurons in the TRPV1 population regulate pain and 1tch," Neuron, 68, No. 3, 529-542 (2010).

21. Y. Liu, O. Abdel Samad, L. Zhang, et al., "VGLUT2-dependent glutamate release from nociceptors is required to sense pain and suppress itch," Neuron, 68, No. 3, 543-556 (2010). 